\title{
Combined orthotopic heart transplantation followed by autologous stem cell transplantation in a patient with light chain amyloidosis and isolated cardiac involvement
}

\author{
Vito Maurizio Parato ${ }^{a}$, Daniela Clemente ${ }^{a}$, Francesca Muscente ${ }^{a}$, Michele Scarano ${ }^{a}$, \\ Ugolino Livi ${ }^{b}$, Negri Francescoc, Rossana Bussanid, Nicoletta Finatoe, \\ Francesca Patriarca ${ }^{f}$, Raffaella Stocchif, Mauro Driussig ${ }^{f}$, Gianfranco Sinagrac \\ a Cardiology Unit, Madonna del Soccorso Hospital, San Benedetto del Tronto, Italy \\ ${ }^{b}$ Department of Cardiothoracic, University Hospital of Udine, Italy \\ " Cardiovascular Department, Division of Cardiology, "Ospedali Riuniti and University of Trieste", Trieste, Italy \\ 'Department of Pathology and Morbid Anatomy, "Ospedali Riuniti and University of Trieste", Trieste, Italy \\ e Department of Medical and Biological Sciences, University of Udine, Udine, Italy \\ ${ }^{f}$ Division of Hematology, Bone Marrow Transplant Unit, Department of Medical and Morphological Research, University \\ Hospital "Santa Maria della Misericordia", Udine, Italy \\ g Division of Cardiology, Cardiothoracic Department, University Hospital "Santa Maria della Misericordia", Udine, Italy
}

\section{ARTICLE INFO}

\section{Article history:}

Received: 25. 6. 2017

Received in revised form: 1. 10. 2017

Accepted: 3. 10. 2017

Available online: 8. 11. 2017

Klíčová slova:

AL amyloidóza

Ortotopická transplantace srdce

Transplantace autologních

kmenových buněk

Keywords:

Autologous stem cell transplantation Light chain amyloidosis

Orthotopic heart transplantation

\section{SOUHRN}

Popisujeme př́pad AL amyloidózy spolu s izolovaným postižením myokardu. Vzhledem k obrazu refrakterního srdečního selhání byla u pacienta provedena ortotopická transplantace srdce. U srdečního štěpu byla zjištěna významná infiltrace střední vrstvy srdeční stěny. $O$ deset měsíců později byla u pacienta provedena transplantace autologních kmenových buněk s príźnivým výsledkem. Tento prípad dokazuje, že ortotopická transplantace srdce s následnou transplantací autologních kmenových buněk u vysoce selektovaných pacientů s AL amyloidózou je život zachraňujícím výkonem.

() 2017, ČKS. Published by Elsevier Sp. z o.o. All rights reserved.

\section{ABSTRACT}

We present a case of amyloidosis AL with isolated myocardial involvement. Because of a refractory heart failure picture, patient underwent orthotopic heart transplant (OHT). The replaced heart showed an important midwall infiltration. Ten months after he underwent autologous stem cell transplantation (ASCT) with a favorable outcome. The case demonstrates that $\mathrm{OHT}$ followed by ASCT in highly selected patients with light chain amyloidosis is a life-saving procedure. 


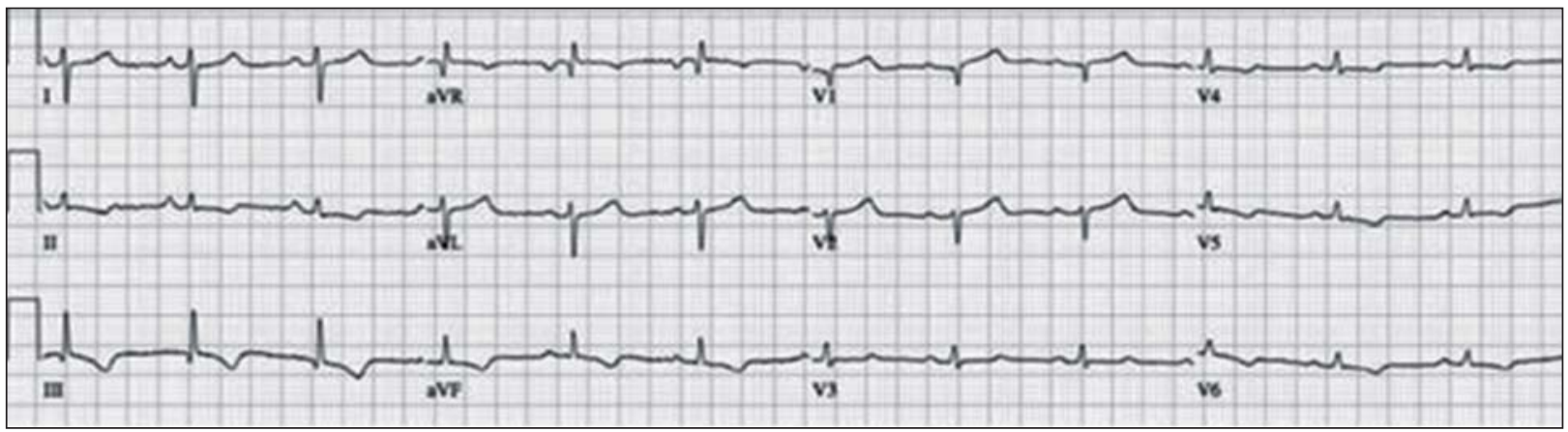

Fig. 1 - The EKG shows low voltages.

\section{The case}

A 44-year-old male was admitted to emergency department because of sudden onset of exertional dyspnea, hand numbness and skin purple.

The EKG demonstrates sinus rhythm and low voltages on the precordial leads (Fig. 1).

He underwent transthoracic echocardiography demonstrating high left ventricle concentric hypertrophy (maximum thickness $28 \mathrm{~mm}$ ) and ground glass texture of the left ventricle walls with preserved ejection fraction (EF) (left ventricle EF: 65\%) (Fig. 2).

The diagnosis of cardiac amyloidosis was performed by endo-myocardial biopsy specimens that showed: myocellular with loss of myofibrillar material, nuclear hypertrophy and apoptotic nuclei, important thickening of intramural arterioles, and Congo-Red staining positive for amyloid, with polarized light, the amyloid has the typical "apple-green" birefringence (Fig. 3A and 3B). Proteinuria with lambda chain confirmed the diagnosis: amyloidosis $A L$ with isolated myocardial involvement given that all remaining soft tissues were infiltration-free.

Bone marrow aspirate showed $17 \%$ plasma cell infiltration.

Thalidomide and dexamethasone were soon started but failed even after bortezomib addition.

A new re-admission, due to NYHA class impairment, occurred. EKG showed atrial fibrillation treated with electrical cardioversion.
Because of a severe (persistent NYHA class IV) and refractory heart failure picture, he underwent orthotopic heart transplant (OHT). The replaced heart showed an important midwall infiltration (Fig. 4).

After high dose melphalan therapy (melphalan 0.22 $\mathrm{mg} / \mathrm{kg}$ once daily for 4 days per week with prednisone 40 mg daily for 4 days per week), ten months after he underwent to autologous stem cell transplantation (ASCT) (Fig. 3).

Nowadays, seven years after the double transplantation, monoclonal components are not present either in serum or in urine. There are no transplant rejection signs.

$\mathrm{He}$ is hemodynamically compensated with normal troponin and NT-proBNP levels [1] and there is a complete hematological remission. He is back to a normal life with a persistent NYHA class I.

\section{Discussion}

Prognosis for patients with light-chain amyloid and cardiac infiltration has historically been dismal, and extensive cardiac involvement has generally been regarded as a contraindication to stem cell transplantation [1,2].

In 1988 cardiac transplantation began to be used to treat $\mathrm{AL}$ amyloidosis patients with overt heart failure [3].

Since then heart transplantation (HT) has been offered to a small number of patients with amyloid cardiomyopathy. The use of this advanced treatment option has been

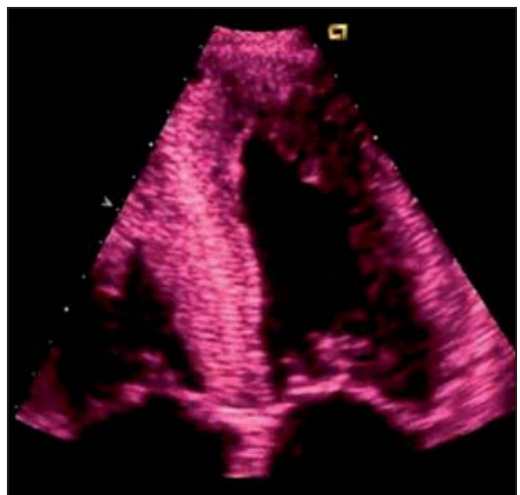

Fig. 2 - The transthoracic echocardiogram four-chamber view shows the ground glass texture of the left ventricle walls and the thickness of the mitral valve.

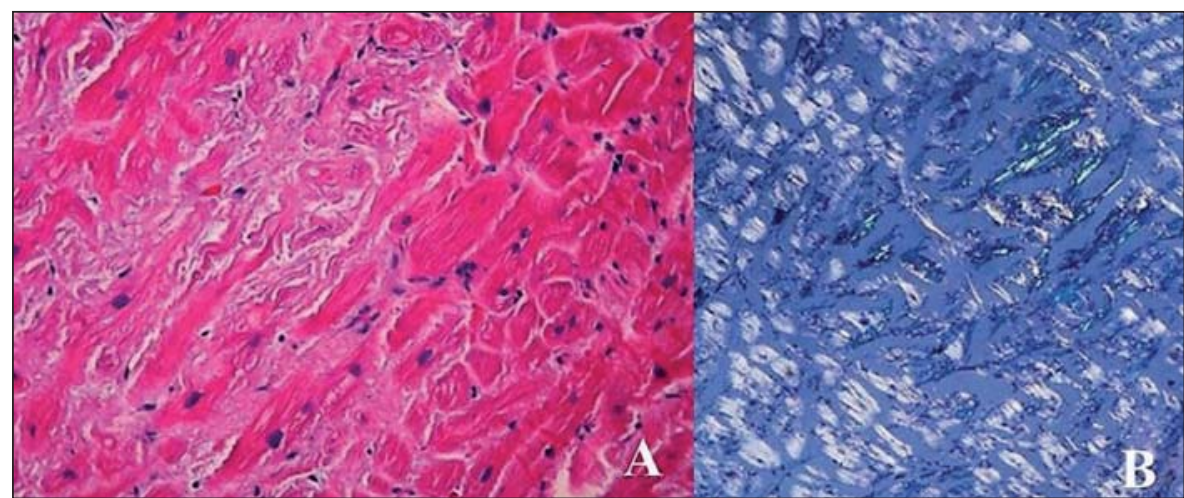

Fig. 3 - The biopsy specimens shows Congo red positive for amyloid (A), with polarized light, the amyloid has an "apple-green" birefringence (B). 


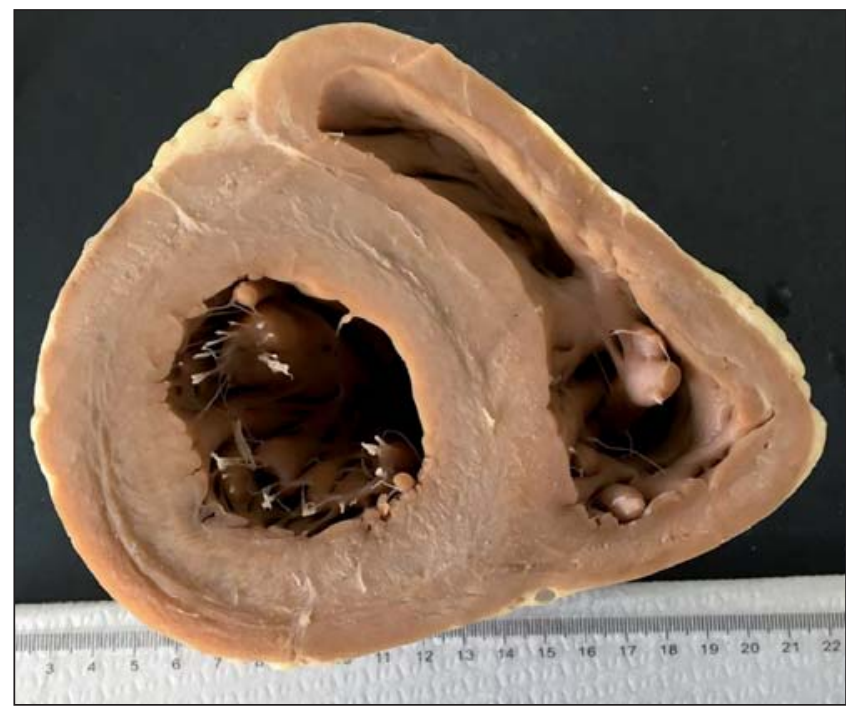

Fig. 4 - The short axis section of the replaced heart shows severe biventricular concentric hypertrophy with midwall infiltration by amyloidosis.

largely restricted to a few experienced centers, and has been controversial [3].

Davis et al. [4] conducted a review of patients undergoing heart transplantation (HT) at their institution for amyloid cardiomyopathy (ACM) between 2008 and 2013. After a median follow-up of 380 days, 17/19 (89.5\%) patients were alive. Their results suggest that acceptable outcomes following HT can be achieved in the short-to-intermediate term and that this is a feasible option for end-stage ACM with careful patient selection and aggressive control of amyloidogenic light chains in AL patients [4].

In patients with $\mathrm{AL}$ amyloidosis, early control of pathogenic light chain production is imperative and can prevent subsequent deposition of amyloid fibrils in the cardiac allograft.

ASCT was not shown to have superior outcomes to oral chemotherapy in the only randomized trial performed to date [5]. Standard oral chemotherapy has continued to evolve since this trial, and now consists of several highly effective and well tolerated regimens in addition to or as an alternative to ASCT [3].

Clinicians should prioritize aggressive control of light chains in AL patients through early initiation of chemotherapy prior to HT, early reinitiation of chemotherapy as soon as patients are clinically stable post-HT, and use of post-HT ASCT in selected patients. ASCT could be not mandatory, particularly in patients who are able to maintain hematologic remission with standard chemotherapy alone.

The investigation published by B.R. Dey et al. [6] demonstrated that cardiac transplantation followed by ASCT is feasible in selected patients with $A L$ amyloidosis and heart failure, and that such a strategy may lead to improved overall survival. In their investigation six of seven patients undergone HT followed by ASCT achieved a com- plete hematologic remission, and one achieved a partial remission [6].

Kobbe et al. [7] said that allogeneic blood stem-cell transplantation using minimal conditioning is a new, promising treatment option for patients with hematologic malignancies after solid-organ transplantation.

\section{Conclusions}

Due to the natural course of the disease, urgent OHT after cardiac manifestation is mandatory.

OHT followed by ASCT in highly selected patients with light chain amyloidosis is a life-saving procedure that treats complex and often fatal diseases.

The tandem approach of OHT followed by high-dose melphalan and ASCT is a feasible strategy and can improve the survival of carefully selected patients with systemic $A L$ amyloidosis who present with overt heart failure.

\section{Conflict of interest}

The authors of this manuscript have no conflicts of interest to disclose.

\section{Funding body}

None.

\section{Ethical statement}

Authors state that the research was conducted according to ethical standards.

\section{Informed consent}

I declare, that informed consent requirements do not apply to this manuscript.

\section{References}

[1] A. Dispenzieri, M.A. Gertz, R.A. Kyle, et al., Serum cardiac troponins and $\mathrm{N}$-terminal pro-brain natriuretic peptide: a staging system for primary systemic amyloidosis, Journal of Clinical Oncology 22 (2004) 3751-3757.

[2] G. Merlini, D.C. Seldin, M.A. Gertz, Amyloidosis: pathogenesis and new therapeutic options, Journal of Clinical Oncology 29 (2011) 1924-1933.

[3] R. Conner, J.D. Hosenpud, D.J. Norman, et al., Heart transplantation for cardiac amyloidosis: successful one-year outcome despite recurrence of the disease, Journal of Heart Transplantation 7 (1988) 165-167.

[4] M.K. Davis, P. Kale, M. Liedtke, et al., Outcomes after heart transplantation for amyloid cardiomyopathy in the modern era, American Journal of Transplantation 15 (2015) 650-658.

[5] A. Jaccard, P. Moreau, V. Leblond, et al., High-dose melphalan versus melphalan plus dexamethasone for $\mathrm{AL}$ amyloidosis, New England Journal of Medicine 357 (2007) 1083-1093.

[6] B.R. Dey, S.S. Chung, T.R. Spitzer, et al., Cardiac transplantation followed by dose-intensive melphalan and autologous stemcell transplantation for light chain amyloidosis and heart failure, Transplantation 90 (2010) 905-911.

[7] G. Kobbe, U. Germing, M. Aivado, et al., Treatment of secondary myelodysplastic syndrome after heart transplantation with chemotherapy and nonmyeloablative stem-cell transplantation, Transplantation 74 (2002) 1198-1200. 